\title{
Application of New media Based on Mobile media in Ideological Education in Universities
}

\author{
Wei Cui* \\ Suzhou University of Science and Technology, Jiangsu 215009, China.
}

\begin{abstract}
Jixin Media has brought new development opportunities and challenges to ideological education for college students. It not only enriches ideological education resources, innovates ideological and political teaching methods, but also improves the effectiveness of ideological education. The article analyzes the positive effect of mobile phone new media on ideological education in colleges and universities, and analyzes the negative problems of the application of mobile phone new media in ideological education in colleges and universities, and proposes the strategy of using mobile new media in ideological education in colleges and universities. Keywords:Ideological education; Mobile media; New media
\end{abstract}

\section{The positive effect of mobile phone new media on ideological education in colleges and universities}

\subsection{Enrich the spiritual connotation of ideological education}

The development of modern mobile internet technology using mobile phones as carriers has been relatively mature. For example, social networking service platforms such as QQ, Weibo, and WeChat are more popular with college students. These internet-based social platforms are more popular than traditional ideological and political education models. Visualization, liberalization and convenience. With the help of mobile terminals such as mobile phones and the use of social networking platforms such as QQ, Weibo, and WeChat, we were able to express the boring ideological and political education content more in line with the characteristics of college students' interests ${ }^{[1]}$.

\subsection{Innovative thinking education methods}

Modern college students have a strong sense of self and are influenced by various ideas in society. Education is conducted to cultivate students' personal abilities. College students have fewer opportunities to contact the society and emotional fluctuations ${ }^{[2]}$. The use of mobile media to carry out ideological and political education can better enter the student group, avoid conflicts, and make teaching tasks more efficient. Completed. The new media represented by mobile phones can build a three-dimensional ideological and political education system for us. If we can occupy the ideological and political education positions of the new media, the channels of ideological and political education will be greatly expanded.

\subsection{Improve the efficiency of ideological education}

The application of mobile phones in college students can greatly expand the various channels of ideological and political education. Through the use of mobile phones, students can freely and flexibly receive the content of ideological and political education anytime, anywhere, so that ideological and political education is no longer limited to the classroom. Using new media to carry out ideological education can effectively increase the number of audiences and expand their influence on college students.

\section{The current situation of ideological education in universities using mobile phone new media applications}

2.1 College students are over-reliant on mobile new media

Mobile phones and mobile devices have also brought some negative impacts on students' daily lives. Students are too dependent on mobile phones, and entertainment software is emerging in the newly developed smart phones, which interferes with learning. This shows that the pros and cons of mobile phones coexist. If unreasonable use not only fails to reflect the advanced nature, its negative effects will also hinder the development of ideological and political education. As an information acquisition and communication tool, the mobile phone is intended to facilitate people's lives ${ }^{[3]}$. However, due to the weak self-control ability of college students, they are easy to become slaves of mobile phones, so they put too much energy into the virtual society displayed by mobile phones, making college students addicted to the virtual society and unable to extricate themselves, even confusing the virtual society with the real society, resulting in college students. Psychological problems occur frequently.

Copyright (C) 2020 Wei Cui

doi: 10.18282/1-e.v9i4.1662

This is an open-access article distributed under the terms of the Creative Commons Attribution Non-Commercial License (http://creativecommons.org/licenses/by-nc/4.0/), which permits unrestricted non-commercial use, distribution, and reproduction in any medium, provided the original work is properly cited. 


\subsection{Increase the difficulty of ideological education}

First of all, as the work that affects people's ideological and political work, it is the educator itself who has a crucial impact on the achievements of ideological and political education. Secondly, the ideological and political education work using mobile phones as tools also puts forward higher requirements for the media literacy of ideological educators. Because the main force for the implementation and development of ideological and political education work is mostly highly respected scholars or workers in the ideological and political field on campus, these educators are usually forced by a large number of work pressures, and they cannot guarantee sufficient media literacy to participate in ideological and political education ${ }^{[4]}$. The time of training and learning has led to the lack of excellent professional level of ideological and political education among these educators, and the development of ideological and political education cannot achieve the best educational effect.

\section{The application of new mobile phone media in college ideological education strategies}

\subsection{Broaden the new media platform for university students' ideological and political education}

The Central Committee of the Youth League proposed to make full use of the Internet and new media to broaden the work platform for ideological and political education. The Central Committee of the Communist Youth League has put forward more new requirements for the ideological and political education of colleges and universities. In order to increase the number of students' ideological and political education audience and educational effects, we must actively expand the platform of ideological and political education for college students, including mobile phones. When broadening the mobile phone platform for ideological and political education of college students, we must first understand the students' mobile phone application habits. For example, we can maintain the spirit of pioneering and innovation in the operation of Weibo and WeChat public accounts by opening the official Weibo and official WeChat public accounts of colleges and universities, not only to realize the innovation of ideological and political education methods, but also to realize ideological and political Innovation of educational content. And according to the current status of college students' thoughts and hotspots, actively update the content of Weibo and WeChat public accounts.

\subsection{Strengthen the construction of new media atmosphere on campus}

Excellent campus culture is a manifestation of the core development momentum of a university. Campus culture can play a profound role in the formation and development of students' outlook on life, moral sentiment, ideological connotation and behavior patterns through colorful content and various forms. Impact. Strengthening the construction of campus culture is conducive to the cultivation of college students' ideological and moral qualities, and enhances the effectiveness of ideological and political work. If we want to enhance the influence of ideological and political education on contemporary college students, we must adopt other methods and adopt methods that are more in line with the ideological characteristics of college students to carry out ideological and political education for contemporary college students. On the one hand, it cooperates with the traditional propaganda work of ideological and political education in the past; on the other hand, the ideological and political education of college students using mobile phones as media can create a new multi-faceted ideological and political education environment for contemporary college students. Once this all-round ideological and political education environment is cleverly integrated with campus culture, it will inevitably play a positive role in guiding college students' thoughts.

\subsection{New ways of mobile phone media construction}

Carrying out ideological and political education for college students not only requires the majority of students to understand the basic theoretical knowledge of the ideological and political education curriculum, but also allows them to use the basic theoretical knowledge they have learned to analyze related practical issues. Therefore, the ideological and political education of college students should use a variety of evaluation methods, not just evaluation by way of exams, but through short stories, recording interview works, etc., to investigate the practical problems of college students applying the basic theoretical knowledge of ideology and politics Level and ability. Using a variety of evaluation methods can better stimulate the interest of students in the ideological and political courses, prompt them to actively participate in classroom activities, and fully reflect the dominant position of college students, so that college students can deeply understand the knowledge of ideological and political education The positive role in real life strengthens college students' emphasis on ideological and political education.

\section{Conclusion}

Ideological and political education for college students should make full use of the advantages and powerful functions of the new media of mobile phones, aiming at the specific problems in the current teaching, from the aspects of teacher media literacy, WeChat platform, traditional excellent culture, teaching models and methods, evaluation methods, etc. The new media is scientifically and reasonably applied to all links of ideological and political education, in order to further improve the effectiveness of ideological and political education and promote the healthy and comprehensive development of the students.

\section{References}

[1]Zhang L . Analysis on Penetrative Effects of New Media on Ideological and Political Education of Universities and Colleges[J]. Open Journal of Social Sciences, 2015, 03(12):207-211.

[2]Ren Zongyi. Study on the Application of New Media to Ideological and Political Education in Guizhou Colleges and Universities_-A Case Study of Guizhou Education University[J]. Journal of Guizhou Teachers College, 2016, 032(004):84-89. [3]An Z Q . Study on the Ideological and Political Education in Universities in New Media Era[J]. 2017.

[4]Chen Guangqiao. Exploration on the Application of New Media in Entrepreneurship Education in Colleges and Universities. Application of New Media in Entrepreneurship Education in Colleges and Universities[J]. Theoretical Research and Practice of Innovation and Entrepreneurship, 2018, 001(018):60-61. 